\title{
Corporate Development Using Open-System Diagnostic Model
}

\author{
Satria Efandi ${ }^{1}$, Muhammad Nur Syuhada ${ }^{2}$ \\ ${ }^{1}$ Ahmad Dahlan University, Magister Psikologi Profesi, Yogyakarta 55166, Indonesia \\ satriaefandi@gmail.com \\ ${ }^{2}$ Ahmad Dahlan University, Magister Psikologi Profesi, Yogyakarta 55166, Indonesia \\ mnursyuhada09@gmail.com
}

\begin{abstract}
Corporate development is carried out to help achieve the corporate's strategic goals and plans. Development begins with analyzing the components that characterize the corporate. The purpose of this study is to determine the condition of the corporate using an open-system diagnostic model which then determines the direction of its development based on the results of the diagnosis. The research subjects were 10 employees with staff and manager levels in one corporate. Data were collected by means of interview, observation and document study instruments. The data were analyzed qualitatively based on the findings of each integrated instrument. Based on the results of the diagnosis, there are several problems that prevent the corporate from improving its work. The most significant problem is the ineffective application of corporate culture that affects all aspects of corporate performance. The form of development proposed is the re-implementation of corporate culture. The diagnostic model provides an understanding in identifying the condition of the corporate from various aspects. The problems identified were intervened in the form of implementing corporate culture in order to improve the quality of its performance.
\end{abstract}

Keywords: Corporate development, diagnostic, open-system

\section{Introduction}

The mode of transportation has a very important role in supporting the business world, industrial and trade growth and is a business segment that can contribute to national economic development (Pujianto, 2016). One type of transportation mode that plays an important role in the economy in Indonesia is rail. The train itself is widely used both as a means of commercial transportation for the public and as a means of logistical transportation between regions and transportation for business purposes. Trains in Indonesia have developed over time so that Indonesia is also able to produce its own trains.

On the other hand, another challenge that is currently being faced is in terms of the intensity of the use of rail transportation in the community. The growing and expansion of private vehicles at affordable prices will potentially turn people's interest towards private forms of transportation rather than public transportation such as trains. One of the largest railway industries in Southeast Asia is PT. X. PT. X as a railroad manufacturing industry answers this challenge with optimism in the future that the railroad business in Indonesia will never die. This is because the train was chosen because it is still a safe, comfortable, and affordable mode of mass transportation. It is proven that big cities in the world continue to use railways to overcome congestion which is an impact of economic growth and drives human mobilization.

However, to answer the challenges and conditions of the train needs, PT. X still has some drawbacks. Companies in terms of service and retail services companies have decreased. The lack of growth in terms of service is caused by the corporate's current focus on producing trains only so that it does not place too much emphasis on other services outside of the train production activities that are obtained from customers.

PT. X is still cleaning up to improve the work system in the corporate as a whole and is fully focused on pursuing the production targets that are obtained as quickly as possible, resulting in several production activities experiencing obstacles and being neglected as well as decreasing production quality. The production quality problem is also reinforced by the complaints submitted by customers about the products produced. Meanwhile, based on the theme of complaints found, there were customers who complained in terms of the quality of train components, the manufacturing process and the train operational system. For the highest complaint is aimed at the quality of train components which are less and easily damaged and the existence of defective train components. Then there were complaints about the train production process that did not comply with standards and damage during the operation of the train after it was received by the customer and used.

Lack of production quality and problems related to the corporate's operational results above are caused not only by factors of raw materials and corporate systems, but also by the human resources in it. According to Amansyah \& Siregar (2020), the human resource factor plays an important role in determining whether or not the performance

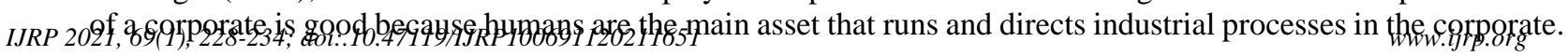


If the quality of human resources owned by the corporate is good, it can be predicted that the performance and results of the corporate will also be of quality. In connection with this, a mapping of the condition of the corporate is needed and an overview of the corporate's problems is obtained so that this can be used as a basis for developing the corporate (Hardiansyah \& Firmansyah, 2017). For the purposes of corporate mapping, it is necessary to identify objectively and systematically in understanding the existing problems, supported by proper analysis, and are expected to be able to provide effective solutions to deal with them. One approach that can be used as a guide in objectively identifying corporate conditions is the open-system organizational diagnostic model offered by Cummings \& Worley (2015).

\section{Literatur Review}

\subsection{Open-system}

According to Cummings \& Worley (2015), the main principle of open-systems is that companies are in a broader environmental context that influence each other because of the interaction between the corporate and the environment. The open-system model applied at the corporate level shows that the corporate operates in an external environment, taking inputs from the environment and transforming these inputs using social and technical processes. The output from the transformation process is then returned to the environment and can be used as feedback on the corporate's functions. In other words, understanding how the corporate is fully functional is necessary to examine matters regarding inputs, process systems (component design), and the alignment of these two dimensions in shaping the output.

\subsubsection{Input}

In the firm level analysis the intended input is that which is obtained from the environment that plays a role in the process or transformation to produce output. The environment that affects the corporate can be identified into 3 categories (Cummings \& Worley, 2015), namely the general environment, the task environment, and the perspective environment. The general environment refers to all external forces that either directly or indirectly affect a corporate. The task environment refers to the corporate structure represented by elements such as suppliers, consumers, threat of substitution, threat of entry, stakeholders and competitors. Whereas the perspective environment refers to the corporate's perceptions and representations of the general environment and the work environment.

\subsubsection{Component design}

Cumming \& Worley (2015) explain that component design is the way a corporate converts inputs into outputs that involve the aspects that make up the corporate's operational activities, which consist of :

\section{a. Strategy}

Strategy represents the way a corporate uses its resources to achieve its goals and gain competitive advantage. Strategy determines how a corporate positions itself to compete in an environment.

b. Technology

Technology deals with the way companies convert inputs into products or services. Technology can be defined as a broader terminology other than equipment or machines which includes production methods, work flows, and work methods.

c. Structure

The structure serves as a basic entrepreneurial tool that is useful for dividing the work of a corporate as a whole into subunits that can assign tasks to groups or individuals. Structure is also useful in coordinating subunits to get the job done as a whole.

d. Management process

Includes methods for processing information, making decisions, and controlling corporate operations. It is used to help companies understand the quality of their own performance, detect and control deviations from goals or objectives, make relevant decisions and communicate corporate performance results.

e. Human Resource System

Includes mechanisms for selecting, developing and training, assessing, and rewarding and incentivizing corporate members.

f. Culture

Culture represents the basic assumptions, values and norms that are shared and believed by corporate members. the corporate culture is accepted by all members and serves as a guide for the perceptions, thoughts, and actions of its members. 


\subsubsection{Output}

The corporate's output is seen as a measure of how well the component design in the corporate contributes to the corporate's effectiveness. Outputs that can be taken into consideration are financial performance, productivity, stakeholder satisfaction, customer satisfaction and the welfare of corporate members. The open-system framework provides an output role in the corporate as a benchmark and a picture of the success of managing the corporate as a whole. If the output produced is bad, low or not in accordance with the corporate's target, it can be used as an indicator of problems that can be traced from the existing processes in the corporate (Rahimi, 2020).

\section{Research Methodology}

The diagnostic model used to analyze problems in the corporate is to use an open-system model which refers to the corporate's diagnosis by Cummings \& Worley (2015). Open-system is a set of concepts and corporate relationships, the system is seen as a unit consisting of subsystems. This system functions to integrate these components into one very functional unit (Rahimi, 2020).

Data collection methods used were interview, observation, and document study instruments. Interviews according to Poerwandari (Santi \& Rachmad, 2018) are a method of collecting data by giving direct questions to respondents to obtain certain information. Interviews were conducted in a structured manner using an interview guide that was structured systematically based on the theoretical framework of the open-system diagnostic model. The interview subjects were 10 corporate employees consisting of staff and manager level employees from various functions in the corporate such as human resource management, system development, quality management, corporate development and the implementation of occupational health and safety. Next, observations, which are observations made by researchers by going directly to the location to observe all the behaviors and activities that you want to track (Manila, 2017). Observations are made by observing business processes and work behavior in the corporate and recording the results of observations based on the theoretical framework of the open-system diagnostic model. Next is a document study which is a data collection technique through searching and finding evidence that is not directly aimed at the object under study, but through documents (Nilamsari, 2017). Document studies were carried out to obtain detailed, detailed and accurate data that were not included in other data collection instruments (Erianjoni, 2018; Ariani, Yuliartini \& Mangku, 2020). In addition, the data in the document study have been validated and can be accounted for because they have been authorized by the corporate. The document study in this research was carried out by collecting and analyzing the contents of the document which was adapted to the theoretical framework of the open-system diagnostic model.

The data analysis was done qualitatively. Qualitative analysis according to Bogdan and Biglen (Moleong, 2017) is an effort made by working with data, commercializing data, sorting it into units that can be managed, synthesizing, looking for and finding patterns, finding what is important and what is learned and decide what to tell others. The qualitative analysis in this study was carried out by interpreting and describing the field findings of each instrument into the theoretical framework of the open-system diagnostic model. After the results of the interpretation of each instrument are obtained, data integration is carried out to obtain a comprehensive understanding in understanding the condition of the corporate.

\section{Research Findings}

The results consisted of identifying the findings of the corporate's condition based on the aspects contained in the theoretical framework of the open-system diagnostic model. The findings are summarized from the 3 instruments used. The explanation of the findings is done by describing the dynamics of the corporate's condition from the findings of the corporate aspects based on the theoretical framework of the open-system diagnostic model. The analysis is presented by explaining the condition of the input of the corporate, then it is explored how the corporate with the capacity it has to respond and process these inputs to produce a certain form of output. The explanation of the findings is presented as follows.

The dynamics of the problems that arise first are on the side of the strategy used by the corporate. The business strategy within the corporate indirectly influences several existing systems within the corporate such as work methods, management processes and business process control, to the human resource management system. First, the influence of corporate objectives and policies on work methods is when the corporate tries to accommodate various customer requests and needs so that every stage of the design and installation process and selection of train components is always communicated with the customer.

Next, the influence of corporate goals and policies on corporate management processes and production quality control can be seen through system adjustments applied to control and maintain corporate managerial consistency, one of which is based on directions from the main leadership and synchronized with the applied business process patterns. Another policy is in the form of cooperation with vendors regarding the development of certain work methods and production methods which are deemed to require updating in accordance with the competence of the vendor. 
The human resource management system in the corporate is also strongly influenced by the corporate's vision, mission and objectives, such as the implementation of training, employee competency development, to recruitment and selection activities. The direction of employee development in the corporate is also determined by the corporate's vision and mission and long-term plans. The effect of this will be seen in which portion of employee development will be focused on each year and the allocation of funds intended for related employee development programs.

Furthermore, the corporate's most prominent strategy is to pursue production targets and efforts to expand market share by developing new quality and product designs. To achieve this, the corporate cooperates with a number of other countries in the context of procuring production machines, adding a specialist or expert workforce, to updating industrial technology. The corporate also seeks to pursue planned production targets by shortening and tightening the duration of product completion to consumers. Even though the employee's condition is not sufficient in terms of quantity and quality, the corporate continues to pursue production completion time by increasing the corporate's daily working time so that many employees are found working overtime. This also causes an increase in employee workload due to cutting production time in order to compete with competitors. However, this is not supported by sufficient internal aspects of the corporate such as more efficient business processes and work methods and raw materials which sometimes still experience delays in delivery to companies or the wrong and defective raw materials. As a result, some products still experience delays in production and there are still some products that have not completed quality checks so they are prone to damage when operated.

Furthermore, the second is about the technological factors that are applied in the production process such as the methods and work procedures used. Every position in the corporate has standard work standards and there are several procedures for the operation of work tools and machines. Employees who work as operators have also received certain certifications in operating heavy work equipment that require special skills. However, it is found in the field that there are still employees who are less disciplined in complying with these procedures and there are other negligence that are prone to causing errors in work to work accidents.

The corporate's management process is also influenced by the corporate's strategies and policies on the management of audit activities, implementation of $\mathrm{K} 3$ and the function of superiors in controlling work processes. In the implementation of corporate audits, it was found that several functions were still ineffective in carrying out their operational activities and their contributions to other units were not effective enough. Then from the aspect of implementing quality control, it was also found that because the corporate was trying to catch up with the fulfillment of production targets, several functions tended to ignore elements of monitoring and review of their respective work results. In addition, it was found that there were repetition of work errors and a lack of emphasis on enforcing safety elements within the corporate environment. Lack of enforcement of this element is caused by employee awareness.

This corporate has a functional structure, where all internal policies and activities are determined by the main leadership, making the function of the superior from both the division to the unit scale an important impact on the pattern and performance of its employees, especially at the staff position level. Broadly speaking, superiors have played a pretty good managerial role towards their subordinates. However, superiors are still not able to form employee synergy with other units or divisions effectively and superiors are still not able to fully assist in developing individual employee capacity. This is because superiors also hold multiple roles and diverse jobs so that sometimes they don't have the opportunity to focus maximum development on their subordinate staff. This has an impact on the performance and quality of work of employees which are still not significantly contributing to the achievement of corporate goals. In addition, employees also feel that they are still not completely satisfied with the roles and work results that have been shown so far because employees feel that they have not had the opportunity to develop themselves and actualize themselves completely as part of the corporate.

However, on the other hand, the climate of interaction and cooperation that is formed between superiors and subordinates and fellow employees has been quite well established, this causes employees to feel satisfied and happy with the kinship climate that is formed without any element of discrimination either personally or collectively. Employees also help each other if someone is having difficulties. In addition, there are also several activities carried out by employees outside of formal working hours where employees gather to strengthen mutual friendship by carrying out various activities together.

From the aspect of human resource management, it can be found in quantity that the corporate has carried out its main functions completely. However, in terms of quality it is still not optimal to have an impact in advancing the corporate. From the aspect of the employee's job itself, the job description and job specifications are still not perfectly integrated. Then from the aspect of competency development, the corporate also does not have a hard competency formula that should be used as the main benchmark for being able to carry out specific jobs. This also has an impact on the ineffective performance of employees in carrying out other functions within the corporate. This ineffective condition of the resource management system also has the potential to threaten the quality of performance and job satisfaction of employees.

Next is about corporate culture. The corporate has core values which have been formulated for a long time. However, at this time it was found that employees had not fully implemented the existing corporate culture and 
employees only knew the terms of these values without understanding deeply their use and how to implement them into work. These cultural values are expected to function as guidelines for effective and quality employee performance.

Furthermore, regarding the output aspects produced by the corporate, it was found that based on productivity there were two assessments, namely positive and negative. The positive aspect of the current productivity of the corporate is the increase in production capacity and the corporate's sales are increasing. In addition, the corporate's health level is still considered to be in a good category. Then the negative side from the production aspect is that the quality of the product is still considered not good. This is because there are several products that have experienced assembly errors as well as defects in production and use of trains that are not durable. The overall negative factors of product quality are due to several internal business process constraints such as damage to equipment and machines, inadequate employee capacity, as well as ineffective production management and control systems and supporting systems to produce excellent products and services.

Furthermore, from the financial aspect, it was found that the corporate got an increase in profits. This increase in profit was due to the corporate's efforts to expand market share and was able to complete several projects in large numbers. However, the corporate also incurs quite a lot of financial expenses due to internal corporate affairs such as vendor rental, recruitment of special experts, and costs for repairing damaged or repaired work tools and machines that require renewal.

On the other hand there is also a condition of customer satisfaction which is a concern for the corporate. There are a number of responses to customer dissatisfaction which are expressed in the form of complaints and complaints. The complaints encountered were about product quality and after-sales service. These complaints and complaints arise due to ineffective production and control of these activities so that product quality is not considered in detail. The human resource factor also has an impact in this case where employees who work in core sectors such as fabrication, technology and finishing are not yet fully competent and have high professionalism to maintain their respective work results.

Apart from that regarding performance, employees appear to be quite good in terms of technical skills, but from the soft skill aspect there are still many things that need to be addressed and improved both by the employees themselves and at the corporate policy. Personally, employees feel satisfaction in two aspects, namely in terms of finance and family relationships that are built within the corporate. However, there are still some dissatisfaction factors where employees complain about the difficulty for them, especially contract employees and staff, to move up the career ladder in the corporate. This is indeed supported by the finding that career paths in companies do not have a clear formula and promotions are obtained only through assessment. Employees are also not satisfied with the opportunities available for them to be able to develop themselves further.

Overall business processes and activities carried out within the corporate are largely determined by the external environment of the corporate and the corporate's leadership itself. The form of this influence is then responded to by employees in the corporate in accordance with the prevailing corporate culture. It is necessary to take several integrated steps in integrating the capabilities of the corporate and employees in it to move forward and make changes. One form of development that can be done in support of this strategy is to develop the corporate culture.

\section{Discussion Analysis}

The open-system diagnostic model is one of the tools that can be used in developing a corporate. This model explains that the corporate in carrying out its business activities is always related to the internal and external environmental aspects that interact with each other. Diagnose is also needed to identify the current weaknesses and strengths of the corporate in achieving its goals (Herdiansyah \& Firmansyah, 2017).

Based on the results of identification and analysis using an open-system diagnostic model, it is known that there are several problems that constrain the corporate from developing and improving its production quality. The first problem lies in the strategy that the corporate uses to compete with competitors by pursuing quantitative production targets has not been effective because the corporate is trying to push the production time limit which is getting shorter with less human capacity and technology. In this context, the corporate should be able to map what it needs as well as the policies of the leadership in it (Hardiansyah, Sumantri, Zaitun, Mellita \& Mukran, 2019). Identification activities should be carried out objectively and systematically in accordance with business processes (Thoha, in Adawiyah, 2018). Identification of the conditions and needs of the corporate is also needed to help develop performance targets that are more compatible with the corporate's capacity (Rezaee, Azar, Moghbel \& Dehghan, 2018).

Then there are obstacles regarding the not implementing production quality control methods to ensure that products do not experience errors and there is no strong mechanism to maintain internal business processes in accordance with industry standards and consumer demand. The control process of the work process is needed to ensure whether the products produced are in accordance with the predetermined plans and designs, both physical and functional (Hidayatullah, 2017; Kurniawan, 2020; Pradana \& Pradana, 2019).

Furthermore, related to the human resource management program implemented by the corporate, the results have not been felt significantly by other employees, such as ineffective training targets, the impact of ineffective 
counseling, unclear career path systems and sub-optimal employee competency development. Even though human research itself within the corporate is seen as a key asset to move the corporate to achieve its goals (Lussier \& Hendon, 2017; Potgieter \& Mokomane, 2020). In order to be able to optimally support the achievement of corporate goals, existing human resources need to be trained, developed and managed appropriately according to their respective capacities and fields of work (Hosain \& Rahman, 2016; Amstrong \& Tylor, 2020).

One of the significant factors that influence this is that employees do not understand how to implement corporate culture into their work processes so that the work behavior displayed by employees still does not reflect the corporate culture, such as lack of discipline in work procedures, negligence in work, quality of work still lacking, and uniformity regarding performance is also difficult to achieve. This also has an impact on employee performance that is not in accordance with corporate expectations and lack of employee awareness in obeying and maintaining their performance and being responsible for their respective fields of work. This is because there is no form of socialization and internalization of corporate culture to employees. The culture that appears in the corporate is only an artifact that has not been updated and re-evaluated for a long time. In addition, there is no measurement and evaluation of the extent to which the culture is understood and applied by employees in their work. The corporate culture should be able to influence the formulation and implementation of strategy and the corporate's ability to achieve high levels of performance (Tirauyah \& Sibuea, 2018; Hastuti \& Wiratno, 2020). A strong corporate culture will be able to have an impact on a sense of belonging and identity for employees as a unit within the corporate (Thakre \& Shroff, 2016; Sutrisno, 2019). The implementation of corporate culture itself needs to involve the interaction of all employees from various levels of positions to be able to understand together the corporate culture used as a code of conduct in accordance with the corporate's vision and mission and goals (Harwiki, 2016; Iriviranty, 2018).

\section{Conclusion}

The open-system diagnostic model illustrates that the corporate is trying to improve its ability to carry out production with more sophisticated technology and seeks to expand market share in order to achieve a competitive advantage. However, in the efforts and strategies for self-development there are several problems that arise, especially in business processes regarding the production process and human resource management. Both problems are caused by the lack of application of corporate culture, which is the main guideline for maintaining the quality of work in accordance with corporate demands. The corporate culture which should be a reference for performance in order to produce more valuable contributions is in fact still lacking in the field and the current culture is only conveyed in writing without any evaluation and follow-up. Therefore, interventions were made to assist employees in implementing the values contained in the corporate culture

The method proposed to be applied in implementing corporate culture aims to deepen the meaning of employees regarding the importance of corporate culture to work. The hope is that the better the application of culture within the corporate, it will provide useful value for employees to work so that the corporate's goals are also achieved.

\section{References}

Adawiyah, R. (2018). Strategi Pengembangan Badan Usaha Milik Desa (BUMDes) Berbasis Aspek Modal Sosial (Studi pada BUMDes Surya Sejahtera, Desa Kedungturi, Kecamatan Taman, Kabupaten Sidoarjo) (Doctoral dissertation, Universitas Airlangga).

Ariani, N. M. I., Yuliartini, N. P. R., \& Mangku, D. G. S. (2020). Implementasi Undang-Undang Nomor 11 Tahun 2012 tentang Sistem Peradilan Pidana Anak Terhadap Curanmor yang dilakukan Oleh Anak di Kabupaten Buleleng (Studi Kasus Perkara Nomor: B/346/2016/Reskrim). Jurnal Komunitas Yustisia, 2(2), 100-112.

Armansyah, A., \& Siregar, S. (2020, February). Analisis Penerapan Akuntansi Sumber Daya Manusia Sebagai Aset Pada Lembaga Filantropi. In Seminar Nasional Teknologi Komputer \& Sains (SAINTEKS) (Vol. 1, No. 1, pp. 601-606).

Armstrong, M., \& Taylor, S. (2020). Armstrong's handbook of human resource management practice. Kogan Page Publishers.

Cummings, T. G., \& Worley, C. G. (2015). Organization development \& change (15. Aufl.). Stamford: Cengage Learning

Erianjoni, E. (2018). Pengembangan Materi Ajar Sosiologi tentang Mitigasi Bencana Berbasis Kearifan Lokal di Kota Padang. SOCIUS, 4(2), 96-107.

Hardiyansyah, H., \& Firmansyah, A. (2017). Analisis Pengembangan Organisasi Melalui Proses Diagnosa Dengan Model Weisbord. Jurnal Manajemen Dayasaing, 19(2), 152-162.

Hardiyansyah, H., Sumantri, A., Zaitun, A., Mellita, D., \& Mukran, M. (2019). Analisis Pengembangan Organisasi Pelayanan Publik melalui Proses Diagnosa dan Intervensi. Jurnal Ilmiah Administrasi Publik, 5(1), 42-49.

Harwiki, W. (2016). The impact of servant leadership on organization culture, organizational commitment, organizational citizenship behaviour (OCB) and employee performance in women cooperatives. Procedia-Social and Behavioral Sciences, 219(1), 283-290.

Hasuti, A. T. A., \& Wiratno, A. (2020). Pengaruh Budaya Organisasi, Tekanan, Kesempatan, Dan Rasionalisasi Terhadap Perilaku Korupsi. Jurnal Ekonomi, Bisnis, dan Akuntansi, 22(2), 113-123.

Hidayatullah Elmas, M. S. (2017). Pengendalian kualitas dengan menggunakan metode statistical quality control (SQC) untuk meminimumkan produk gagal pada toko roti barokah bakery. WIGA: Jurnal Penelitian Ilmu Ekonomi, 7(1), 15-22.

Hosain, S., \& Rahman, M. D. (2016). Green human resource management: A theoretical overview. IOSR Journal of Business and Management (IOSR-JBM) Volume, 18. 
Iriviranty, A. (2018). Analisis Budaya Organisasi dan Budaya Keselamatan Pasien Sebagai Langkah Pengembangan Keselamatan Pasien di RSIA Budi Kemuliaan Tahun 2014. Jurnal Administrasi Rumah Sakit Indonesia, 1(3).

Kurniawan, J. I. (2020). Kontrol Kualitas Pada Produksi Concrete Block Di Pt. Panen Raya Kencana, Banyuwangi. Jurnal Dimensi Pratama Teknik Sipil, 9(2), 187-194.

Lussier, R. N., \& Hendon, J. R. (2017). Human resource management: Functions, applications, and skill development. Sage publications.

Moleong, L. (2017). Metodologi Penelitian Kualitatif, Rosda.

Nilamsari, N. (2017). Memahami studi dokumen dalam penelitian kualitatif. WACANA: Jurnal Ilmiah Ilmu Komunikasi, $13(2), 177-181$.

Potgieter, I. L., \& Mokomane, S. E. (2020). Implementation of human resource management functions in selected small manufacturing companies in Ga-Rankuwa industrial area, Gauteng, South Africa. SA Journal of Human Resource Management, 18(1), 1-11.

Pradana, T., \& Pradana, W. A. A. (2019). Sistem Informasi Pengendalian Kualitas Untuk Mengetahui Cacat Produk Pipa. Jurnal SPIRIT, 11(1).

Pujianto, J. (2016). Analisis Peranan Infrastruktur Moda Transportasi Kereta Api Terhadap Pertumbuhan Ekonomi Suatu Wilayah (Studi Pada Wilayah Jawa Timur: Daop VII Madiun, Daop VIII Surabaya dan Daop IX Jember) (Doctoral dissertation, Universitas Brawijaya).

Rahimi, H. (2020). A Comparative Study of Organizational Pathological Patterns: A Strategy for Iranian Organizations. Iranian Journal of Comparative Education, 3(4), 907-921

Rezaee, Z., Azar, A., Moghbel, A., \& Dehghan Nayeri, M. (2018). Diagnosing organizational structure based on the viable system model (VSM). Modern Research in Decision Making, 3(1), 187-215.

Santi, M. D. M., \& Rachmad, N. (2018). Gambaran Body Image Pasien Pasca Amputasi Transtibial Setelah Menggunakan Transtibial Prosthesis. Jurnal Keterapian Fisik, 3(2), 89-99.

Sutrisno, H. E. (2019). Budaya organisasi. Prenada Media.

Thakre, N., \& Shroff, N. (2016). Organizational Climate, Organizational Role Stress and Job Satisfaction among Employees. Journal of Psychosocial Research, 11(2).

Tirauyah, P. S., \& Sibuea, A. M. (2018). Effect of Principal Managerial Supervision Organization Climate and Work Satisfaction to the Performance of School Health SD Negeri In Medan. 